Received Date : 25-Jan-2013

Revised Date : 25-Jan-2013

Accepted Date : 29-Jan-2013

Article type : Primary Research Articles

\title{
Detrimental effects of Ocean Acidification on the economically important Mediterranean red coral (Corallium rubrum)
}

\section{Running title: Ocean Acidification Corallium rubrum}

${ }^{12}$ Bramanti L., ${ }^{2}$ Movilla J., ${ }^{3}$ Guron M., ${ }^{2}$ Calvo E., ${ }^{5}$ Gori A., ${ }^{2}$ Dominguez-Carrió C., ${ }^{2}$ Grinyó J., ${ }^{2}$ Lopez-Sanz A., ${ }^{2}$ Martinez-Quintana A., ${ }^{24}$ Pelejero C., ${ }^{36}$ Ziveri, P., ${ }^{3}$ Rossi S.

${ }^{1}$ California State University Northridge. 18111 Nordhoff st. 91330 Northridge, CA, USA

${ }^{2}$ Institut de Ciències del Mar, ICM-CSIC, Passeig Marítim de la Barceloneta 37-49, 08003, Barcelona, Spain

${ }^{3}$ ICTA-UAB, UAB Campus Cn s/n Cerdanyola del Vallés 08193 Barcelona, Spain.

${ }^{4}$ Institució Catalana de Recerca i Estudis Avançats (ICREA), Barcelona, Spain

${ }^{5}$ Centre Scientifique de Monaco, Avenue Saint Martin 98000 Monaco, Principality of Monaco

${ }^{6}$ Department of Earth Sciences - Earth and Climate, Faculty of Earth and Life Sciences, VU Universiteit Amsterdam de Boelelaan 1085, 1081HV Amsterdam, The Netherlands

Corresponding author: Lorenzo Bramanti Tel: +1 8184708903 e-mail: philebo@gmail.com

Keywords: Mediterranean red coral; Metabolic effects of Ocean Acidification; Climate change; Economic impact of Ocean Acidification; Calcification; Biochemical balance.

Type of paper: Primary Research Article

This article has been accepted for publication and undergone full peer review but has not been through the copyediting, typesetting, pagination and proofreading process, which may lead to differences between this version and the Version of Record. Please cite this article as doi: $10.1111 / \mathrm{gcb} .12171$

(C) 2013 Blackwell Publishing Ltd 


\begin{abstract}
The mean predicted decrease of 0.3 to $0.4 \mathrm{pH}$ units in the global surface ocean by the end of the century has prompted urgent research to assess the potential effects of ocean acidification on the marine environment, with strong emphasis on calcifying organisms. Among them, the Mediterranean red coral (Corallium rubrum) is expected to be particularly susceptible to acidification effects, due to the elevated solubility of its $\mathrm{Mg}$-calcite skeleton. This, together with the large overexploitation of this species, depicts a bleak future for this organism over the next decades. In this study, we evaluated the effects of low $\mathrm{pH}$ on this species from aquaria experiments. Several colonies of $C$. rubrum were longterm maintained for 314 days in aquaria at two different $\mathrm{pH}$ levels $\left(8.10\right.$ and $\left.7.81, \mathrm{pH}_{\mathrm{T}}\right)$. Calcification rate, spicule morphology, major biochemical constituents (protein, carbohydrates and lipids) and fatty acids composition were measured periodically. Exposure to lower $\mathrm{pH}$ conditions caused a significant decrease in the skeletal growth rate in comparison to the control treatment. Similarly, the spicule morphology clearly differed between both treatments at the end of the experiment, with aberrant shapes being observed only under the acidified conditions. On the other hand, while total organic matter was significantly higher under low $\mathrm{pH}$ conditions, no significant differences were detected between treatments regarding total carbohydrate, lipid, protein and fatty acid composition. However, the lower variability found among samples maintained in acidified conditions relative to controls, suggests a possible effect of $\mathrm{pH}$ decrease on the metabolism of the colonies. Our results show, for the first time, evidence of detrimental ocean acidification effects on this valuable and endangered coral species.
\end{abstract}

\title{
1. Introduction
}

Ocean acidification $(\mathrm{OA})$ is considered a major threat to the marine environment in the coming years (Doney et al. 2009). An average reduction of $0.1 \mathrm{pH}$ units has already affected the surface waters of the world's oceans since the pre-industrial era (Orr et al. 2005) and future projections predict a decrease by 0.3 to $0.4 \mathrm{pH}$ units by the end of the century, depending on the considered $\mathrm{CO}_{2}$ emission scenarios (e.g. Joos et al. 2011). Although OA acts at a global scale, its impact varies locally. In the case of the Mediterranean Sea, the fast turnover time of its waters (50-100 years; Bethoux et al. 2005) and the very high concentration and fast penetration of anthropogenic $\mathrm{CO}_{2}$ (Schneider et al. 2007; Schneider et al. 2010; Touratier \& Goyet 2009) makes it one of the world's most sensitive regions to increasing atmospheric $\mathrm{CO}_{2}$ (Ylmaz et al. 2008; Calvo et al. 2011, Ziveri 2012). A recent study estimated a $\mathrm{pH}$ decrease of up to 0.14 units since the pre-industrial era (Touratier \& Goyet 2011), larger than the global averaged surface ocean $\mathrm{pH}$ decrease of $\sim 0.1 \mathrm{pH}$ units 
recognised normally (e.g. Orr et al. 2005). The Mediterranean Sea is also characterized by other important environmental stressors (e.g. Calvo et al. 2011; Durrieu de Madron et al. 2011) which can impact marine organisms and ecosystems in different ways, in many instances synergistically (Crain et al. 2008; Lejeusne et al, 2010; Coll et al, 2010).

Several studies examining the potential impact of the projected $\mathrm{pH}$ levels on marine organisms have shown a wide variety of responses (e.g. Doney et al. 2009; Guinotte \& Fabry, 2008; Ries et al. 2009; Wicks \& Roberts 2012; Suggett et al. 2012). In the case of coral reef communities, most experiments indicate that the decreased concentration of carbonate ion associated to the reduction in $\mathrm{pH}$ has a detrimental effect, hindering the calcification process and the skeleton formation (e.g., Kroeker et al. 2010; Chan \& Connolly 2012 and references therein). However, the calcification process in corals is highly complex and the impact of OA on critical physiological/biochemical mechanisms controlling the $\mathrm{pH}$ at the site of calcification is still poorly understood (Allemand et al. 2011; Cohen \& Holcomb 2009). There is evidence that some species have the capacity to raise $\mathrm{pH}$ and $\left[\mathrm{CO}_{3}^{2}\right]$ at the calcifying site (Al-Horani et al. 2003; Cohen \& McConnaughey 2003; Ries 2011; Trotter et al, 2011), yet this active physiological process requires a significant amount of energy and a high metabolic cost for the organism (Wood et al. 2008; Cohen \& Holcomb 2009; Edmunds et al. 2012; Li \& Gao 2012; McCulloch et al, 2012). It is likely that the rate of change and the magnitude of seawater $\mathrm{pH}$ decrease are key factors in determining the energy demand for this process, reducing its availability to undertake other activities such as locomotion, reproduction, tissue growth or to counteract other environmental stresses (Brewer \& Peltzer 2009; Hoegh-Guldberg et al. 2007). Therefore, studies aiming to identify which metabolic pathways can be more influenced by OA may play a helpful role to understand such an effect. 
OA could also have clear regional socio-economic ramifications such as those related with the reduction in the harvest of high commercial interest species (Cooley et al. 2009). One of these key species is the red coral, Corallium rubrum (Linnaeus 1758), the so-called "Mediterranean Red Gold". It is a long-lived, slow-growing gorgonian endemic to the Mediterranean Sea and its neighbouring Atlantic rocky shores, where it can be found between 10 and $600 \mathrm{~m}$ depth (Costantini et al. 2010; Rossi et al. 2008). It is considered as one of the most valuable precious corals due to its bright red durable skeleton used as raw material in the jewellery industry (Tsounis et al. 2010). For these reasons, C. rubrum has been harvested since ancient times and it is now considered overexploited (Santangelo et al. 2004). Moreover, due to its rarity, cultural importance and landscape aesthetic value, red coral can be considered as a patrimonial or flagship species of the Mediterranean Sea (Bramanti et al. 2011). Red coral is composed of an axial skeleton and sclerites coated with living tissue (coenenchyma). The external surface of the coenenchyma is formed by the ectoderm, under which the mesoglea lies, a thick acellular layer of collagen containing small sclerites (30-50 $\mu \mathrm{m})$. The axial skeleton has the same mineralogical composition than the free sclerites $(\mathrm{Mg}-$ rich calcite, Vielzeuf et al. 2008) but it is not the product of their fusion (Grillo et al. 1993). The main function of the sclerites is to provide mechanical protection against abrasion (Allemand 1993), although it has been suggested that they may act as temporary stocks of $\mathrm{CaCO}_{3}$, readily available for the formation of the axial skeleton (Vielzeuf et al., 2008). The solubility of Mg-rich calcite minerals is greater than that of aragonite or calcite (Plummer \& Mckenzie, 1974), and the seawater saturation state with respect to carbonate minerals decreases with increasing latitude (Andersson et al. 2008; Orr et al. 2005). Thus, it is conceivable that Mg-rich calcite, temperate calcifying organisms such as C. rubrum should be more susceptible to the decrease of $\mathrm{pH}$ conditions and among the first to be affected by these new environments. 
Owing to the demand for management and conservation plans for a sustainable harvesting of this precious octocoral (Brukner \& Roberts 2009; Bussoletti et al. 2010; GFCM 2010, 2011), dynamic models have been developed, projecting demographic trends over time (Santangelo et al. 2007; Bramanti et al. 2009). However, there is a lack of information regarding future OA effects in these colonies with potential to be harvested. To shed light on this topic, we investigated the effect of $\mathrm{OA}$ on $C$. rubrum by simulating in aquaria the future $\mathrm{pH}$ conditions projected by the end of the century. The potential changes in calcification rate, sclerite morphology and biochemical composition of the colonies reared under different $\mathrm{pH}$ conditions were evaluated. The results provide valuable information on the response of $C$. rubrum to low $\mathrm{pH}$ conditions that will increase our understanding and capacity to forecast the economic and ecological consequences of OA impacts on this precious species.

In this study, we aimed at answering the following questions: (1) Does a lowering in $\mathrm{pH}$ affect the $\mathrm{CaCO}_{3}$ deposition in $C$. rubrum?; (2) What is the effect of $\mathrm{OA}$ on the morphology of sclerites?; (3) How does OA affect the metabolic balance of colonies in terms of total organic matter, carbohydrates, proteins, lipids and fatty acids?; (4) Could OA lead to different physiological responses related with the organism's capability to store energy?; (5) How will OA affect the harvestable stocks of red coral?

\section{Materials and methods}

\subsection{Specimen collection and experimental setup}

Colonies of $C$. rubrum were carefully removed from rocky substrates at $35-40 \mathrm{~m}$ depth from the Marine Protected Area of Cap de Creus (Spain, NW Mediterranean Sea, $42^{\circ} 19^{\prime} \mathrm{N}$; $003^{\circ} 19^{\prime} \mathrm{E}$ ) in November 2010 when in situ temperature was $13^{\circ} \mathrm{C}$. The collected specimens were transported in large seawater containers at constant temperature $(12.5 \pm$ $0.5^{\circ} \mathrm{C}$ ) to the Institut de Ciències del Mar (ICM CSIC) in Barcelona (Spain). Colonies were 
maintained in a $100 \mathrm{~L}$ acclimation tank with $50 \mu \mathrm{m}$ filtered running natural seawater at in situ temperature and salinity conditions $\left(12^{\circ} \mathrm{C}\right.$ and 37.6 , respectively). As the red coral commercially harvested populations dwells between 80 and 100 meters depth (Tsounis et al, 2013), where the seasonal temperature variation are very small, colonies in the tanks were maintained at constant temperature and in complete darkness. For feeding, de-frozen Cyclops (Ocean Nutrition ${ }^{\mathrm{TM}}$ ) were supplied daily ( $\sim 55 \mathrm{mg}$ of dry weight per aquarium). After 1 month of acclimation, 48 colonies of C. rubrum (Fig. S1) were selected and randomly distributed among 6 aquaria (30 litres each). Aquaria were further subdivided into 2 treatments ( 3 replicates per treatment), control $\mathrm{pH}$ and low $\mathrm{pH}$ (see below). The experimental set up is shown in Fig. S2. Seawater pH was gradually adjusted (0.03 units per day) in two large tanks of $150 \mathrm{~L}$ up to $\sim 8.10$ and $\sim 7.81 \mathrm{pH}$ units (total scale) simulating, respectively, the Mediterranean seawater in equilibrium with an atmosphere of $\sim 380 \mathrm{ppm} \mathrm{CO}_{2}$ (current levels) and $~ 800 \mathrm{ppm} \mathrm{CO}_{2}$ (future levels predicted for year 2100 following A2 IPCC SRES; Plattner et al. 2008). In order to achieve the desired $\mathrm{pH}$ levels, seawater was bubbled with $\mathrm{CO}_{2}$ (99.9\% purity) or $\mathrm{CO}_{2}$-free air (using a filter filled with soda lime absorber, Sigma Aldrich). Seawater pH was continuously monitored by glass electrodes (LL Ecotrode plus - Metrohm) connected to a pH controller (Consort R316, Topac Inc., USA). The glass electrodes were calibrated on a daily basis with a Tris buffer, following standard procedures (SOP6a of Dickson et al. 2007). In addition, small volumes of water were taken periodically (once a month during the first 3 months and bimonthly for the rest of the experiment) to analyse total alkalinity (TA) by potentiometric titration (Perez \& Fraga, 1987; Perez et al. 2000) and pH using spectrophotometry (Clayton \& Byrne 1993), which provides better precision than electrodes. TA and $\mathrm{pH}$ were used to calculate the rest of parameters of the carbonate system in seawater in both treatments, using the $\mathrm{CO}_{2}$ calc software (Robbins et al. 2010) (Table S1). Water from the large tanks flowed continuously ( $12 \mathrm{~L}$ per hour) to the experimental aquaria where colonies were maintained. Water in each aquarium was mixed with a pump (HYDOR 
Koralia; $4.5 \mathrm{~W}, 1500 \mathrm{l} \mathrm{h}^{-1}$ ) and a plastic wrap was used to reduce evaporation and surface-air gas exchange. The $\mathrm{pH}$-manipulative experimental set-up was installed inside a temperaturecontrolled room, ensuring constant values $\left(\sim 12^{\circ} \mathrm{C}\right)$ during the whole experiment.

C. rubrum colonies were sampled quarterly, from December 2010 (Time 0) to November 2011 (Time 3). During each sampling event, the buoyant weight of all the colonies was measured and 6 random colonies ( 1 from each experimental aquarium) were removed and kept at $-80^{\circ} \mathrm{C}$, subsequently freeze-dried and then stored frozen at $-20^{\circ} \mathrm{C}$ until morphological and biochemical analyses were undertaken. Furthermore, at the end of the experiment, one extra colony was randomly selected from each aquarium to estimate specific microdensity and porosity.

\subsection{Skeletal measurements}

Changes in growth of the $C$. rubrum colonies $(n=30)$ were assessed from measurements of buoyant weight (Jokiel et al. 1978; Davies 1989), using a $0.1 \mathrm{mg}$ resolution balance (Mettler Toledo AB204 SFACT). During the measurements, temperature and salinity of seawater were constantly monitored using an YSI-30M probe. The net buoyant weight of the corals (total coral weight minus the coral holder and glue) was transformed to dry weight using the specific density value of $2.66 \mathrm{~g} \mathrm{~cm}^{-3}$ (see below). The increase in weight was normalized to their initial mass and the growth rate $(\mathrm{G})$ is expressed as $\mathrm{mg}$ of $\mathrm{CaCO}_{3}$ increase per gram of initial weight per day. This normalization was used for statistical analyses.

Microdensity and porosity of the skeleton of $C$. rubrum were evaluated following the Bucher et al.'s (1998) technique. For this, one colony from each aquarium (3 per treatment) was dipped in sodium hypochlorite during two days to remove the organic matter and washed with distilled water. Buoyant weight and dry weight of each sample were recorded before and 
after the inclusion in molten paraffin wax $\left(105-110^{\circ} \mathrm{C}\right)$ to form a water-tight barrier. In both cases, the buoyant weight was measured in distilled water at $20^{\circ} \mathrm{C}$ with specific density $1.00 \mathrm{~g}$ $\mathrm{cm}^{-3}$. Total enclosed volume, skeleton matrix volume and bulk density were also calculated for each sample using the equations described in Bucher et al. (1998).

\subsection{Sclerite morphology}

Following the methodology described in Lewis \& von Wallis (1991) and Gori et al. (2012a), a sample of about $5 \mathrm{~mm}$ length of each colony, taken at approximately mid height of the branches, was dipped in sodium hypochlorite solution until organic matter was dissolved and sclerites were disaggregated. After sedimentation, the samples were rinsed with distilled water and subsequently with absolute ethanol for faster drying during mounting. A small portion of the sample was deposited on a glass cover attached to an aluminium stub with colloidal silver and covered with a thin layer of gold palladium $(<200 \AA)$. Sclerite morphological observations were performed with a Scanning Electron Microscope (SEM) HITACHI S-3500 N working at 5.0 KV. A total of 12 colonies (3 replicates per treatment for time 0 and time 3) were examined and categorized in two main morphological types (Fig S3; Carpine \& Grasshoff 1975). For each colony, 35 sclerites (Type I = 20, Type II = 15) were measured using a magnification of $1300 \mathrm{X}$. Sclerites with an anomalous morphology were labelled as aberrant (Fig. S3). For each sclerite the following measures were recorded by means of the graphic software Image J (Abramoff et al. 2004): Area, perimeter, maximum width and maximum height. In order to describe the overall shape of each sclerite, the following ratios were calculated: area/perimeter, width/height and circularity. The latter, defined as the ratio between the area of the sclerite and the area of a circle with the same perimeter, represents a measure of compactness (Turon \& Becerro, 1992).

\subsection{Major biochemical constituents}

Organic matter $(\mathrm{OM})$ of primary branches was determined in 10-12 mg of dry coenenchyma from each colony $(n=24)$. To obtain dry weight, samples were heated at $80^{\circ} \mathrm{C}$ 
for $48 \mathrm{~h}$. The same samples were then ashed for 5 hours at $450^{\circ} \mathrm{C}$ and weighted again. $\mathrm{OM}$ was then calculated as the difference between dry and ash weight (Slattery \& McClintock 1995). Results are expressed as percentage with respect to the initial dry weight of the sample. Approximately $8 \mathrm{mg}$ of dry coenenchyma from each sample were homogenized in $3 \mathrm{ml}$ of double distilled water, and total carbohydrates content was quantified colorimetrically according to the method of Dubois et al. (1956), with glucose as standard. Another $8 \mathrm{mg}$ of coenenchyma dry weight from each sample were homogenized in $2 \mathrm{ml}$ of $1 \mathrm{~N} \mathrm{NaOH}$ and total protein content was quantified colorimetrically using the method of Lowry et al. (1951), with albumin as standard. Finally, approximately $12 \mathrm{mg}$ of coenenchyma dry weight from each sample were homogenized in $3 \mathrm{ml}$ of chloroform-methanol (2:1) and total lipid content was quantified colorimetrically according to the method of Barnes \& Blackstock (1973), using cholesterol as standard. All the results are presented in $\mu \mathrm{g}$ of constituent per mg of OM. These methodologies have already been applied with C. rubrum (Rossi \& Tsounis, 2007).

For fatty acid proportions estimation, approximately $10 \mathrm{mg}$ of dry coenenchyma from each sample were homogenized in 3:1 DCM:MeOH (dichloromethane-methanol), spiked with an internal standard mixture (2-octyldodecanoic acid and $5 \beta$-cholanic acid) and extracted using microwave assisted extraction for $5 \mathrm{~min}$ at $70^{\circ} \mathrm{C}$. After centrifugation, the extract was taken to near dryness in a centrifugal vacuum concentrator at a constant temperature and fractionated by solid phase extraction according to Ruiz et al. (2004). The sample was redissolved in $0.5 \mathrm{ml}$ of chloroform and eluted through a $500 \mathrm{mg}$ aminopropyl glass column (Russell \& Werne 2007) that was previously activated with $4 \mathrm{ml}$ of $n$-hexane. The first fraction was eluted with $3 \mathrm{ml}$ of chloroform:2-propanol (2:1) and the fatty acids recovered with $8.5 \mathrm{ml}$ of diethyl ether:acetic acid (98:2). The fatty acids fraction was methylated using a solution of $20 \% \mathrm{MeOH} / \mathrm{BF} 3$ and heated at $90^{\circ} \mathrm{C}$ for $1 \mathrm{~h}$. The reaction was quenched with $4 \mathrm{ml}$ of $\mathrm{NaCl}$ saturated water. The methyl esters of fatty acids were recovered 
by extracting twice with $3 \mathrm{ml}$ of $n$-hexane. The combined extracts were taken to near dryness, redissolved in $1.5 \mathrm{ml}$ of chloroform and eluted through a glass column filled with $\mathrm{Na}_{2} \mathrm{SO}_{4}$ to remove residual water. After removal of the chloroform under nitrogen gas, the extracted sample was stored at $-20^{\circ} \mathrm{C}$ until analysis by gas chromatography. Samples were redissolved in $80 \mu \mathrm{l}$ of isooctane and gas chromatography analysis was performed with an Agilent Technologies 7820A GC equipped with a flame ionization detector, a splitless injector and a DB5MS Agilent column (60 m length, $0.25 \mathrm{~mm}$ internal diameter and $0.25 \mu \mathrm{m}$ phase thickness). Hydrogen was used as a carrier gas at $30 \mathrm{ml} \mathrm{min}^{-1}$. The oven temperature was programmed to increase from $50^{\circ} \mathrm{C}$ to $160^{\circ} \mathrm{C}$ at $20^{\circ} \mathrm{C} \mathrm{min}{ }^{-1}$, from $160^{\circ} \mathrm{C}$ to $188^{\circ} \mathrm{C}$ at $0.5^{\circ} \mathrm{C}$ $\mathrm{min}^{-1}$, from $188^{\circ} \mathrm{C}$ to $299^{\circ} \mathrm{C}$ at $20^{\circ} \mathrm{C} \min ^{-1}$, from $299^{\circ} \mathrm{C}$ to $235^{\circ} \mathrm{C}$ at $2^{\circ} \mathrm{C} \min ^{-1}$ and from $235^{\circ} \mathrm{C}$ to $300^{\circ} \mathrm{C}$ at $4^{\circ} \mathrm{C} \mathrm{min}^{-1}$. Injector and detector temperatures were set at $300^{\circ} \mathrm{C}$ and $320^{\circ} \mathrm{C}$, respectively. Methyl esters of fatty acids were identified by comparing their retention times with those of standard fatty acids (29 FAME compounds, Supelco® Mix C4-C24). Fatty acids were quantified by integrating the peak areas using the Chromquest 4.1 software, and converting them into concentrations from the area $v s$ concentration of the internal standards.

For fatty acid grouping into classes (total Saturated Fatty Acids, SAFA; Mono Unsaturated Fatty Acids, MUFA and Poly Unsaturated Fatty Acids, PUFA), only those with concentrations higher than $1 \%$ of the total fatty acids were considered (Daalsgaard et al. 2003). This methodology has already been applied in gorgonians (Gori et al. 2012b).

\subsection{Statistical analyses}

A two-way nested ANOVA was used to examine whether calcification rate varied between treatments (i.e., exposure to low $\mathrm{pH}$ conditions and exposure to control $\mathrm{pH}$ conditions) and aquaria. Aquarium was considered as a random factor nested within treatment. A total of 30 colonies (5 per aquarium, 15 per treatment) were weighted. Calcification rate data are expressed as mean \pm standard error (SE). A one-way ANOVA was used to examine differences between both treatments (Control 
and low $\mathrm{pH})$ in microdensity and porosity of the Mg-rich calcite skeleton. Sclerites morphology results were standardized with respect to their median absolute deviation (MAD), and a Euclidean distance matrix was built based on the standardized data. A distance-based permutational multivariate analysis of variance (PERMANOVA; Anderson 2001) was employed to test the null hypothesis of no significant differences between treatments. Factors were time (initial and final time), treatment (control and low $\mathrm{pH}$ ) and aquaria (random factor nested within treatment). Finally, a univariate twoway ANOVA was used to analyse biochemical results. Factors in this case were treatment (control and low $\mathrm{pH}$ ) and time (4 sampling points). When ANOVA showed significant differences, Tukey's honest significant difference test (HSD) was used to attribute differences between specific factors or their interaction only. All biochemical data are expressed as mean \pm standard deviation (SD). In order to have a measure of the variability associated to the response to low $\mathrm{pH}$, the Coefficient of Variation (Standard Deviation / Mean) was calculated. Multivariate analysis was performed using the PERMANOVA software (Anderson 2005), while all the other statistical analyses were performed using the R software platform (R development Team 2012).

\section{Results}

\subsection{Skeletal measurements}

Microdensity and porosity of $C$. rubrum were $2.66 \pm 0.06 \mathrm{~g} \mathrm{~cm}^{-3}$ and $25.7 \pm 5.3 \%$ (mean $\pm \mathrm{SD} ; \mathrm{n}=$ 6), respectively. No significant differences between treatments were observed, neither in microdensity (ANOVA, $\mathrm{F}_{1,5}=5.25, \mathrm{p}=0.08$ ) nor on porosity (ANOVA, $\mathrm{F}_{1,5}=0.42, \mathrm{p}=0.55$ ), indicating that the structural material composition of this gorgonian was not affected by the level of acidification to which it was subjected. Regarding the effect of the lower $\mathrm{pH}$ treatment on the skeletal growth of $C$. rubrum, a significant decrease was observed at the end of the experiment in their averaged calcification rates, which were found to be 59\% lower compared to control conditions (Table 1 and Fig. 1). The survivorship in each treatment was $100 \%$ and no tank effect was detected between aquaria replicates of the same treatment in any analysis. 


\subsection{Sclerites morphology}

PERMANOVA results showed a significant interaction between the factor Time and the factor Treatment for both types of sclerites (type I and II, Fig. S3, Table 2). These results confirm the hypothesis of an effect of low $\mathrm{pH}$ on the overall sclerite shape. The post hoc test showed that at Time 0 (at the beginning of the experiment) there were no significant differences between both treatments while at Time 3 (after 314 days) the overall shape of sclerites of the colonies grown under low $\mathrm{pH}$ conditions was significantly different compared with the control treatment. Furthermore, the presence of anomalous shapes classified as aberrant type (Fig. S3) was detected only in colonies reared in the acidified treatment.

\subsection{Major biochemical constituents}

The analysis of the $\mathrm{OM}$ content showed a significant interaction between the factor "Treatment" and the factor "Time" (Table 3 and Fig. 2). Post hoc comparisons (Table 3) indicated no differences between treatments in $\mathrm{T} 0$ and $\mathrm{T} 1$, while in $\mathrm{T} 2$ and $\mathrm{T} 3$, the mean $\mathrm{OM}$ content of samples in the low $\mathrm{pH}$ treatment remained higher than that in control conditions. While the OM of C. rubrum grown in the control treatment significantly changed from T0 to T3 (Table 3 and Fig. 2), no significant differences were found in the lower $\mathrm{pH}$ conditions throughout the experiment.

Regarding the metabolic balance, no differences between treatments were found in total protein, carbohydrate or lipid content during the whole experiment (Two-way ANOVA, $\mathrm{F}_{3,16}=0.093$, $\mathrm{P}>0.05 ; \mathrm{F}_{3,16}=1.22, \mathrm{p}>0.05 ; \mathrm{F}_{3,16}=0.009, \mathrm{p}>0.05$, respectively). Furthermore, the Coefficient of Variation (CV) was higher in the control samples (Fig 3).

Regarding fatty acids, no significant differences were found between treatments, neither in the total fatty acid levels among the different times (Fig 4; Two-way ANOVA, $\mathrm{F}_{3,16}=0.49, \mathrm{P}>0.05$ ), nor in the fatty acid proportions (SAFA, MUFA and PUFA; Fig S4). As in the previous case, samples reared under control conditions showed higher coefficient of variability values in times 2 and 3 (Fig $4)$. 


\section{Discussion}

\subsection{Changes in the structural features of C. rubrum}

After 314 days of exposure, colonies of C. rubrum reared under lower $\mathrm{pH}$ conditions $(\mathrm{pH} 7.81)$ suffered a decrease in skeletal growth rate of $59 \%$ compared with those maintained in the control treatment $(\mathrm{pH} 8.10)$. This reduction confirms the expected detrimental effects on skeletal formation and it is consistent with previous experimental studies examining the response to OA of other benthic calcifying species. In the case of tropical scleractinian corals, the decline in the calcification rate ranges from $10 \%$ to $60 \%$ at double elevated $p \mathrm{CO}_{2}$ conditions (Guinotte and Fabry, 2008; Kleypas et al. 2006), reaching up to $70 \%$ of reduction in the case of Porites rus at pH 7.80 (Muehllehner \& Edmunds, 2008). Some species, however, are able to calcify even under low saturation state conditions (Jury et al. 2010; Krief et al. 2010; Ries et al. 2010; Comeau et al, 2013), pointing to some complexity in the mechanisms controlling the intracellular calcification process (Ries, 2011 and references therein). Similarly, a wide range of responses has been observed in Mediterranean coral species. Fine \& Tchernov (2007) reported total skeleton dissolution for Oculina patagonica at a pH of 7.4, while Movilla et al (2012) found a 35\% reduction in calcification rates for O. patagonica and Cladocora caespitosa at a pH of 7.83, and Rodolfo-Metalpa et al (2010a) showed no effects of decreased seawater $\mathrm{pH}$ (7.88) on the calcification rates of C. caespitosa. In addition, the only experiment to date in which temperate corals were transplanted to a natural $\mathrm{pH}$ gradient influenced by volcanic $\mathrm{CO}_{2}$ vents, showed evidences of dissolution on the exposed skeleton of $C$. caespitosa at $\mathrm{pH} 7.5$ environments, while no effects were observed in Balanophyllia europaea, which skeleton was completely covered by tissue, at $\mathrm{pH}$ levels as low as 7.3 (Rodolfo-Metalpa et al. 2011). Regarding Mediterranean bryozoans, Schizoporella errata transplanted to the same naturally acidified site showed skeletal corrosion and disruption in calcification at pH 7.76 (Lombardi et al. 2011a). However, the skeletal growth rate and appearance of Myriapora truncata were not affected until a $\mathrm{pH}$ of 
7.43 (Lombardi et al. 2011b; Rodolfo-Metalpa et al, 2010b), suggesting that the presence of organic tissue enveloping the skeleton could play a key role in these organisms (Ries et al, 2009; Rodolfo-Metalpa et al, 2011), providing protection against the corrosiveness of lower $\mathrm{pH}$ seawater. It should be noted that, unlike scleractinian corals or bryozoans as S. errata, whose skeletons are made of calcite or aragonite (Cohen \& McConnaughey, 2003; Smith et al. 2006), the red coral skeletal structure consists entirely of Mg-rich calcite (Vielzeuf et al. 2008). As previously mentioned, the solubility of this latter form is much higher than the first two and, therefore, this species could be considered as one of the most susceptible organisms to $\mathrm{OA}$ in the Mediterranean.

Our results also showed an effect of lower $\mathrm{pH}$ on the morphology of microscopic sclerites, with an overall shape different between treatments and anomalous forms observed only in acidified conditions. Sclerites abnormal skeletogenesis has been observed previously in sea urchin larvae exposed to high $\mathrm{pCO}_{2}$ conditions (Kurihara \& Shirayama, 2004). According to Allemand (1993), the main function of these sclerites in C. rubrum is to ensure the mechanical protection against abrasion, although it has been suggested that they may act as $\mathrm{CaCO}_{3}$ temporary stocks readily available for the axial skeleton formation through mechanisms of dissolution, transport, and recrystallization (Vielzeuf et al. 2008). Furthermore, in the order Alcyonacea, the skeleton is typically proteinaceous (Grillo et al. 1993) with elastic properties that allow the colonies to bend forward and back to an upright position (Jeyasuria \& Lewis, 1987). The morphology and abundance of sclerites in the tissue limit the extent of these movements, being a determinant factor defining their overall structure (Lewis \& Von Wallis 1991). Therefore, our results suggest that, in the long term, OA will affect $C$. rubrum and other gorgonians in compromising the $\mathrm{CaCO}_{3}$ stocking capacity as well as the skeleton biomechanical properties. 
This study focused on evaluating the effect of OA on the growth of a Mediterranean anthozoan with high commercial value such as the red coral. However, in addition to OA, other environmental pressures may affect future red coral populations, acting independently or in synergy with OA. While increased atmospheric $\mathrm{pCO} 2$ is responsible for $\mathrm{OA}$, it is also causing an increase in global seawater temperature. In the Mediterranean Sea, increased seawater temperature has been shown to translate into longer stratification periods associated with mass mortality events (Coma et al. 2009; Garrabou et al. 2009). Although the synergistic effects of warming and ocean acidification could well affect shallow water red coral populations (Santangelo et al. 2012a), the present study has a particular focus on populations with harvest potential (i.e. below 60 meters depth, Rossi et al. 2008), where temperature changes are not as marked and tend to remain relatively constant throughout the year. Nevertheless, high temperatures induce increased metabolic and respiration rates and depress the polyp activity in red coral and other gorgonians (Previati et al. 2010). In addition, longterm exposure to high temperature can result in partial or total mortality of the colonies and recruits (Bramanti et al. 2005; Garrabou et al. 2001, 2009; Torrents et al, 2008). Thus, it is essential to perform future studies manipulating OA and temperature to assess the existence of possible interactions between multiple stressors and establish to which extent coral colonies inhabiting shallower ranges will be threatened.

\subsection{Metabolic response of red coral to a lowering in $\mathrm{pH}$}

Gorgonians skeleton consists of internal formations (central axis and sclerites) protected by a thick layer of mesoglea gel (Alderslade \& Fabricius 2008), a composite material of collagen-like fibrils randomly oriented in a hydrated polymer matrix (Lewis \& von Wallis 1991). The presence of a tissue layer prevents the direct exposure of the skeleton to seawater and may modulate the effects of OA in coral and other organisms (Hoffman et al. 2010; Ries et al. 2009; Rodolfo-Metalpa et al. 2011). However, in our experiment, although 
the tissue of colonies remained intact, a clear effect of high $p \mathrm{CO}_{2}$ in coral growth was observed. In addition to minimizing growth, the colonies of $C$. rubrum reared under acidified conditions may have activated physiological processes to offset the new conditions, with the consequent increase in energy consumption (Al-Horani et al. 2003; Cohen \& Holcomb 2009; Tsounis et al. 2012). Our results on Total Organic Matter tend to point in the direction of this hypothesis. For example, throughout the experiment, higher content of organic matter was observed in the coral colonies reared under lowered $\mathrm{pH}$ conditions in comparison to those in the control, which displayed a progressive lowering in organic matter content with time (Fig. 2). Similar responses were found in more drastic $\mathrm{pH}$ lowering $(\mathrm{pH}$ 7.4) in which the temperate corals $O$. Patagonica and Madracis pharencis were exposed (Fine \& Tchernov, 2007). In this case, polyps of these species suffered a complete dissolution of the skeleton, but their biomass was three times higher than those maintained in control conditions (Fine \& Tchernov, 2007). As it has been described in the case of gastropods, the energy allocation for the shell construction $v s$ that needed to build the organic matrix is very different and changes under stress conditions (Palmer 1983, 1992). Under lowered pH conditions the metabolism is affected (Edmunds 2012; Edmunds et al. 2012) and the energetic cost of calcification is expected to be higher (e.g. Cohen \& Holcomb, 2009). Therefore we hypothesize that $C$. rubrum may respond to decreased seawater $\mathrm{pH}$ be increasing the formation of organic matter, consequently decreasing calcification rates. This response is mediated by an alteration of $C$. rubrum metabolism caused by an increase in the cost of calcification in a low $\mathrm{pH}$ environment.

Total carbohydrate, protein and lipid content in colonies grown under control conditions in the present work were similar to those observed by Rossi \& Tsounis (2007) in natural conditions (Fig. 3), indicating that the biochemical composition of C. rubrum tissue in aquaria is comparable to that observed in situ. Protein and lipid content was also comparable 
to other gorgonians such as Paramuricea clavata and Leptogorgia sarmentosa (Rossi 2002; Rossi et al. 2006). Data on fatty acid concentration of C. rubrum are presented in this work for the first time. Regarding composition, a wide range of fatty acid profiles were observed (Fig. S4) but most of the fatty acid esters were quite similar to those described in the case of zooxanthellate anthozoans (Meyers \& Quinn 1974; Latyshev et al. 1991; Gori et al. 2012b), although azooxanthellate organisms may have other physiological and metabolic mechanisms to counter the effect of external stress.

As mentioned, a larger variability in the total concentration of carbohydrate, protein and lipid content was observed throughout the experiment in the control colonies, whereas the variability was much more reduced in the colonies under the acidified conditions (Fig 3). This difference in response could perhaps be an indication of a more dimmed seasonal trend in the colonies under low $\mathrm{pH}$ pressure than those in the control treatment or the observed under natural conditions (Rossi and Tsounis 2007). This could be due to endogenous processes, dormancy or some kind of life cycle disruption experimented under certain environmental pressures, with the aim of saving energy by reducing or shutting down some physiological processes (e.g. respiration; Previati et al. 2010) and thus, survive. This conforms with the findings on sea urchins Hemicentrotus pulcherrimus and Echinodetra mathei where the fertilization success, developmental rates, larval size, and sclerite skeletogenesis also decreased in those specimens reared under low $\mathrm{pH}$ (Kurihara \& Shirayama 2004) probably because a considerable part of the energy is invested in respiration and in protein synthesis related with basic metabolic paths as found in barnacle and copepods (Wong et al. 2011, Li \& Gao 2012). In coral species, metabolism reduction has also been observed as a defensive mechanism to survive under adverse conditions (Rossi 2002; Previati et al. 2010). Nonetheless, this could translate into less available energy for processes such as growth or reproduction (Brewer \& Peltzer 2009; Hoegh-Guldberg et al. 2007). Our study was 
focused on assessing the effect of lower $\mathrm{pH}$ on skeletal growth rates of $C$. rubrum. However, further research on the effects on reproduction and on the response in a natural seasonal environment should be undertaken to gain deeper insights on the response of red coral populations to OA.

\subsection{Economy and management}

Understanding the population dynamics of the precious Mediterranean red coral is essential to implement best management and conservation strategies for this species under the ongoing rapid climate and environmental change. In summer 1999 and 2003, shallow populations of $C$. rubrum, among other benthic suspension feeders in the northwestern Mediterranean Sea, suffered a mass mortality event due to a temperature anomaly (Bramanti et al. 2005; Cerrano et al. 2000; Coma et al. 2006; Garrabou et al. 2001; 2009; Santangelo et al. 2007; Cupido et al. 2012). These mass mortality events, coupled with the uncontrolled harvesting, could bring some populations to local extinction (Santangelo et al. 2012a). In fact, the distribution and size of red coral have been altered over time (Rossi et al. 2008, Linares et al. 2010). In Cap de Creus (NE Spain), shallow and deep population structures have been affected by management rules (Santangelo et al. 2012b) turning the "coral forest" into "coral grass plain" (Rossi et al. 2008, 2012; Tsounis et al. 2007).

On the other hand, depending on the $\mathrm{CO}_{2}$ emission scenarios, seawater $\mathrm{pH}$ and carbonate saturation states could drop significantly by the end of the century (Joos et al. 2011). The present study shows, for the first time, a negative response of $C$. rubrum deep-water populations to OA. The observed decrease in the calcification rate together with some evidence of a potential reduction in the metabolism of red coral colonies as possible survival mechanism against low $\mathrm{pH}$ conditions, could have negative rebounds on the economy of the jewellery industry linked to this species and lead to a price deflation for years. The market price of the red coral colonies is currently very high: thin 
juvenile branches can be sold for 230-300 US\$ $\mathrm{kg}^{-1}$ while Pacific Corallium sp. colonies with diameter $>4 \mathrm{~cm}$ can reach 50.000 US $\$ \mathrm{~kg}^{-1}$ (Tsounis et al. 2007, 2010). Under the increasing global environmental and economic pressures, causing limited raw material production and possible price deflation, the red coral industry may suffer a decline worldwide. In Europe, red coral industry has significantly declined over time and, today, only 30\% of the coral processed in Torre del Greco (Italy) is C. rubrum, whereas $70-80 \%$ is represented by other species of precious corals imported from Japan and Taiwan (Nonaka \& Muzik 2009; Tsounis et al. 2010; Chen 2012). These economic losses represent more than 230 million ${\mathrm{US} \$ \mathrm{yr}^{-1}}^{-1}$ (Tsounis et al. 2010).

Furthermore, without proper protection and management plans, this slow-growing, endemic precious species of Mediterranean Sea may suffer local extinction in the near future. Young populations of $C$. rubrum may be unable to cope with combined pressures of heat waves, ocean acidification, overexploitation and other anthropogenic activities. Moreover, local extinction and changes in the population structure could affect the role that engineering species (Jones et al. 1994) as C. rubrum play in the benthic pelagic coupling and biogeochemical cycles (Rossi et al., 2012). Data from the present study provide experimental input that can be used in simulations of population trends overtime based on matrix models (Caswell 2001) that will allow making projections on population dynamics under the expected future acidification scenarios. Management and conservation actions should be then planned on the basis of the outcome of these simulations in order to preserve this precious species with the associated biodiversity and the economy linked to its exploitation.

\section{Aknowledgements}

The research has been funded by the EC $7^{\text {th }}$ FP (grant agreement 265103, Project MedSeA) and by the Spanish Ministry of Economy and Competitiveness (MINECO; CTM2009-08849, Project ACDC). The authors are grateful for the invaluable support of the Cap de Creus Marine Protected Area staff. We thank José Manuel Fortuño for assisting us with SEM imaging and the ZAE staff at the ICM for technical assistance. Thanks are also due to TDI and A. Ferrucci for the Megalodon CCR equipment used for underwater sampling and to Eduardo Obis for the pictures. L.B. was supported by a Marie 
Curie IEF fellowship (EC7 ${ }^{\text {th }}$ FP, Project $n^{\text {o }}$ 221072), J.M. by a FPI studentship (BES-2007-16537),

M.G. by of Erasmus Mundus scolarship (contract no. JEMES European UAB 2009/No.3) and S.R. by a Ramón y Cajal Contract (RyC-2007-01327) from MINECO. US National Science Foundation grant OCE 08-44785 provided support to L.B. during part of the writing of manuscript. This is a contribution from the Marine Biogeochemistry and Global Change research group, funded by Generalitat de Catalunya through grant 2009SGR142.

\section{References}

Abràmoff M, Magalhaes PJ, Ram SJ (2004) Image processing with ImageJ. Biophotonics International 11: 36-42.

Alderslade P, Fabricius KE (2008) Octocorals. In: The Great Barrier Reef: biology, environment and management (eds Hutchings PA, Kingsford MJ and Hoegh Guldberg O) pp. 222-245. CSIRO Publishing and Springer.

Al-Horani FA, Al-Moghrabi SM, de Beer D (2003) The mechanism of calcification and its relation to photosynthesis and respiration in the scleractinian coral Galaxea fascicularis. Marine Biology 142, 419-426.

Allemand D (1993) The biology and skeletogenesis of the Mediterranean Red Coral: a review. Precious Corals \& Octocorals Research 2,19-39

Allemand D, Tambutté É, Zoccola D, and Tambutté S (2011) Coral Calcification, Cells to Reefs. (Z. Dubinsky \& N. Stambler, Eds.) Media. Dordrecht: Springer Netherlands. doi:10.1007/978-94-0070114-4.

Anderson MJ (2001) A new method for non-parametric multivariate analysis of variance. Austral Ecology 26, 32-46.

Anderson MJ (2005) PERMANOVA: a FORTRAN computer program for permutational multivariate analysis of variance. Department of Statistics, University of Auckland, New Zealand. 
Andersson AJ, Mackenzie FT, Bates NR (2008) Life on the margin: implications of ocean acidification on Mg-calcite, high latitude and cold-water marine calcifiers. Mar Ecol Prog Ser 373, 265-273.

Barnes H, Blackstock J (1973) Estimation of lipids in marine animals and tissues: Detailed investigation of the sulphophosphovanillin method for total lipids. Journal of Experimental Biology $12,103-118$.

Bethoux, JP, Boukhary, MS, Ruiz-Pino, D, Morin, P, Copin Montegut, C, (2005) Nutrient, Oxygen and Carbon Ratios, $\mathrm{CO} 2$ Sequestration and Anthropogenic Forcing in the Mediterranean Sea. Hdb Environment Chemical 5, 67-86.

Bramanti L, Magagnini G, DeMaio L, Santangelo G (2005) Recruitment, early survival and growth of the Mediterranean Red Coral Corallium rubrum (L 1758), a four-year study. Journal of Experimental Marine Biology and Ecology, 314, 69-78.

Bramanti L, Santangelo G, Iannelli M (2009) Mathematical modelling for conservation and management of gorgonians corals: young and olds, could they coexist? Ecol Mod 20 (21): 28512856.

Bramanti L, Vielmini I, Rossi S, Stolfa S, Santangelo G (2011) Involvement of recreational scuba divers in emblematic species monitoring: The case of Mediterranean red coral (Corallium rubrum). Journal for Nature Conservation 19, 312-318.

Brewer PG, Peltzer ET (2009) Limits to marine life. Science 324, 347.

Bruckner AW, Roberts G, (2009) 1st Int Workshop on Corallium science, management and trade, Hong Kong, 2009. NOAA Tech Memo NMFS-OPR-43:71-86

Bussoletti E, Cottingham D, Bruckner AW, Roberts G, Sandulli R (2010) Proceedings of the International Workshop on Red Coral Science, Management, and Trade: Lessons from the Mediterranean. NOAA Technical Memorandum CRCP-13, Silver Spring, MD 233 pp.

Bucher D, Harriott VJ, Roberts LG (1998) Skeletal micro-density, porosity and bulk density of acroporid corals. Journal of Experimental Marine Biology and Ecology 228, 117-136.

Calvo E, Simó R, Coma R, Ribes M, Pascual J, Sabatés A, Gili JM, Pelejero C (2011) Effects of climate change on Mediterranean marine ecosystems: the case of the Catalan Sea. Climate Research 50, 1-29.

Carpine C, Grasshoff M (1975) Les gorgonaires de la Méditerranée. Bulletin de Institut Oceanographique Monaco, 71(1), 1-140.

Caswell H (2001) Matrix Population Models, second ed. Sinauer Associates, Sunderland, MA. 
Cerrano C, Bavestrello G, Bianchi CN, et al. (2000) A catastrophic mass-mortality episode of gorgonians and other organisms in the Ligurian Sea (NW Mediterranean), summer 1999. Ecology Letters, 3, 284-293.

Chan NCS, Connolly SR (2012) Sensitivity of coral calcification to ocean acidification: a meta-analysis. Global Change Biology 19 (1): 282-290.

Chen CS (2012) Management of the precious coral fishery in Taiwan: Progress and perspectives Marine Policy 36 (3) :623-629.

Clayton TD, Byrne RH (1993) Spectrophotometric seawater pH measurements: total hydrogen ion concentration scale calibration of m-cresol purple and at-sea results. Deep-Sea Research 40, 21152129 .

Cohen AL and Holcomb M (2009) Why corals care about ocean acidification: Uncovering the mechanism. Oceanography, 22(4), 118-127.

Cohen AL and Mcconnaughey T (2003) A geochemical perspective on coral mineralization. Reviews in Mineralogy and Geochemistry, 54(1), 151-187.

Coll M, Piroddi C, Steenbeek J, Kaschner K, Ben Rais Lasram F, et al. (2010) The Biodiversity of the Mediterranean Sea: Estimates, Patterns, and Threats. PLoS ONE 5(8): e11842. doi:10.1371/journal.pone.0011842

Coma R, Linares C, Ribes M, Diaz D, Garrabou J, Ballesteros J (2006) Consequences of a mass mortality in populations of Eunicella singularis (Cnidaria: Octocorallia) in Menorca (NW Mediterranean). Marine Ecology Progress Series 327, 51-60.

Coma R, Ribes M, Serrano E, Jiménez E, Salat J, Pascual J (2009) Global warming-enhanced stratification and mass mortality events in the Mediterranean. Proceedings of the National Academy of Sciences 106, 6176-81.

Comeau S, Carpenter RC, Edmunds PJ (2013) Effects of feeding and light intensity on the response of the coral Porites rus to ocean acidification. Mar Biol DOI 10.1007/s00227-0122165-5

Cooley S, Kite-Powell H, Doney S (2009). Ocean acidification's potential to alter global marine ecosystem services. Oceanography, 22(4), 172-181. 
Constantini F, Taviani M, Remia A, et al. (2010) Deep-water Corallium rubrum (L.,1758) from the Mediterranean Sea: preliminary genetic characterization. Marine Ecology, 31, 261269.

Crain CM, Kroeker K, Halpern BS (2008) Interactive and cumulative effects of multiple human stressors in marine systems. Ecology Letters 11: 1304-1315.

Cupido R, Cocito S, Manno V, Ferrando S, Peirano A, Iannelli M, Bramanti L, Santangelo G (2012) Sexual structure of a highly reproductive, recovering gorgonian population: quantifying reproductive output. Mar Ecol Prog Ser. (in press).

Dalsgaard J, St John M, Kattner G, Müller-Navarra D, Hagen W (2003) Fatty acid trophic markers in the pelagic marine environment. Advances in Marine Biology, 46, 225-340.

Davies PS (1989) Short-term growth measurements of corals using an accurate buoyant weighing technique. Marine Biology, 101(3), 389-395.

Dickson AG, Sabine CL, Christian JR (2007) Guide to best practices for ocean measurements. PICES special publication, 3 .

Doney S, Fabry V, Feely R, Kleypas J (2009) Ocean acidification: the other $\mathrm{CO}_{2}$ problem. Annual Review of Marine Science, 1, 169-192.

Dubois M, Gilles KA, Hamilton JK, Rebers PA, Smith F (1956) Colorimetric method for the determination of sugars and related substances. Analytical Chemistry, 28, 350-356.

Durrieu de Madron X, Guieu C, Sempéré R, Conan P, Cossa D, D’Ortenzio F, Estournel C et al. (2011) Marine ecosystems' responses to climatic and anthropogenic forcings in the Mediterranean. Progress In Oceanography, 91(2), 97-166.

Edmunds PJ, Cumbo VR, Fan TY (2012) Metabolic costs of larval settlement and metamorphosis in the coral Seriatopora caliendrum under ambient and elevated $\mathrm{pCO}_{2}$. Biol Bull (in press).

Edmunds PJ (2012) Effect of $\mathrm{pCO}_{2}$ on the growth, respiration, and photophysiology of massive Porites spp. in Moorea, French Polynesia. Mar Biol 159: 2149-2160

Fine M, Tchernov D (2007) Scleractinian coral species survive and recover from decalcification. Science, 315, 1811.

Garrabou J, Perez T, Sartoretto S, Harmelin JG (2001) Mass mortality event in red coral Corallium rubrum populations in the Provence region (France, NW Mediterranean). Marine Ecology Progress Series, 217, 263-272. 
Garrabou, J, Coma, R, Bensoussan, N, Bally, M, Chevaldonné, P, Cigliano, M, Diaz, D, Harmelin, JG, Gambi, MC, Kersting, DK, Ledoux, JB, Lejeusne, C, Linares, C, Marschal, C, Pérez, T, Ribes, M, Romano, JC, Serrano, E, Teixido, N, Torrents, O, Zabala, M, Zuberer, F, Cerrano, C (2009). Mass mortality in Northwestern Mediterranean rocky benthic communities: effects of the 2003 heat wave. Global Change Biology 15, 1090-1103.

GFCM (General Fisheries Commission for the Mediterranean Scientific Advisory Committee SAC) (2011) Report of the Transversal Workshop on Red Coral Ajaccio (Corsica), France, 5-7 October 2011.

GFCM (General Fisheries Commission for the Mediterranean Scientific Advisory Committee SAC) (2010) Report of the Transversal Workshop on Red Coral Alghero (Sardinia), Italy, 16-17 September 2010. SAC 13/2011/if.

Gori A, Bramanti L, Lopez-Gonzalez P, Thoma J, Gili JM, Grinyo J, Uceira V, Rossi S (2012a) Characterization of the zooxanthellate and azooxanthellate morphotypes of the Mediterranean gorgonian Eunicella singularis. Mar. Biol. 159:1485-1496, DOI:10.1007/s00227-012-1928-3.

Gori A, Villadrich N, Gili JM, Kotta M, Cucio C, Magni L, Bramanti L, Rossi S (2012b) Reproductive cycle and trophic ecology in deep versus shallow populations of the Mediterranean gorgonian Eunicella singularis. Coral Reefs 31(3): 823-837.

Grillo MC, Goldberg WM, Allemand D (1993) Skeleton and sclerite formation in the precious coral Corallium rubrum. Marine Biology 117: 119-128

Guinotte J, Fabry V (2008) Ocean acidification and its potential effects on marine ecosystems. Annual New York Academy Sciences, 1134, 320-342.

Hofmann GE, Barry JP, Edmunds PJ, Gates RD, Hutchins DA, Klinger T, Sewel MA (2010) The effects of ocean acidification on calcifying organisms in marine ecosystems: an organism to ecosystem perspective. Annu. Rev. Ecology, Evolution, and Systematics, 41, 127-47.

Hoegh-Guldberg O, Mumby PJ, Hooten AJ, Steneck RS, Greenfield P, Gomez E, Harvell CD, Sale PF, Edwards AJ, Caldeira K, Knowlton N, Eakin CM, Iglesias-Prieto R, Muthinga RH, Bradbury RH, Dubi A, Hatziolos ME (2007) Coral Reefs Under Rapid Climate Change and Ocean Acidification. Science 318, 1737-1742.

Jeyasuria P, Lewis JC (1987) Mechanical properties of the axial skeleton in gorgonians. Coral Reefs 5:213-219 
Jokiel PL, Maragos JE, Franzisket L (1978) Coral growth: buoyant weight technique. In: Coral Reefs: Research Methods (eds Stoddart DR, Johannes RE), UNESCO monographs on oceanographic methodology, pp 529-542. Paris.

Jones CJ, Lawton JH, Shachak M (1994) Organisms as ecosystem engineers. Oikos 69:373-386.

Joos F, Frölicher TL, Steinarcher M, Plattner GK (2011) Impact of climate change mitigation on ocean acidification projections, in: Ocean acidification (JP Gattuso, L Hansson, eds.), Oxford University Press, Oxford, pp. 272-290.

Jury CP, Whitehead RF, Szmant AM (2010) Effects of variations in carbonate chemistry on the calcification rates of Madracis auretenra (= Madracis mirabilis sensu Wells, 1973): bicarbonate concentrations best predict calcification. Global Change Biology 16, 1632-1644.

Kleypas JA, Feely RA, Fabry VJ, Langdon C, Sabine CL, Robbins LL (2006) Impacts of ocean acidification on coral reefs and other marine calcifiers: a guide for future research. Report of a workshop held 18-20 April 2005, St. Petersburg, FL, sponsored by NSF, NOAA, and the U.S. Geological Survey, 88 pp.

Krief S, Hendy EJ, Fine M, Yam R, Meibom A, Foster GL, Shemesh A (2010) Physiological and isotopic responses of scleractinian corals to ocean acidification. Geochimica et Cosmochimica Acta 74, 4988-5001.

Kroeker, KJ, Kordas, RL, Crim, RN, and Singh, GG (2010). Meta-analysis reveals negative yet variable effects of ocean acidification on marine organisms. Ecology letters, 13(11), 1419-34

Kurihara H, Shirayama Y (2004) Effects of increased atmospheric CO2 on sea urchin early development. Marine Ecology Progress Series, 274, 161-69.

Latyshev NA, Naumenko NV, Svetashev VI, Latypow YY (1991). Fatty acids of reefbuilding corals. Mar. Ecol. Prog. Ser., 76: 295-301.

Lejeusne C, Chevaldonné P, Pergent-Martini C, Boudouresque CF, Pérez T (2009) Climate change effects on a miniature ocean: the highly diverse, highly impacted Mediterranean Sea. Trends Ecol Evol 25 (4): 250-260.

Lewis JC, von Wallis E (1991) The function of surface sclerites in gorgonians (Coelenterate, Octocorallia) . Biology Bulletin, 181, 275-288. 
Li W, Gao K (2012) A marine secondary producer respires and feeds more in a high $\mathrm{CO}_{2}$ ocean. Marine pollution bulletin 1-5.

Linares C, Bianchimani O, Torrents O, Marschal C, Drap P, Garrabou J (2010) Marine protected areas and the conservation of long-lived invertebrates: the Mediterranean red coral. Mar Ecol Prog Ser 402: 69-79

Lombardi C, Gambi MC, Vasapollo C, Taylor P, Cocito, S (2011a) Skeletal alterations and polymorphism in bryozoans at natural $\mathrm{CO}_{2}$ vents. Zoomorphology, 130, 135-145.

Lombardi C, Rodolfo-Metalpa R, Cocito S, Gambi MC, Taylor PD (2011b) Structural and geochemical alterations in the $\mathrm{Mg}$ calcite bryozoan Myriapora truncata under elevated seawater pCO2 simulating ocean acidification. PSZN I: Marine Ecology 32: 211-222

Lowry OH, Rosebrough NJ, Farr AL, Randall RJ (1951) Protein measurement with the Folin phenol reagent. Biological Chemistry, 193, 265-275.

McCulloch M, Falter J, Trotter J, Montagna P (2012) Coral resilience to ocean acidification and global warming through $\mathrm{pH}$ up-regulation. Nature Climate Change 2, 623-627.

Meyers P, Quinn J, Marshall N (1974) A method for analysis of fatty acids in coral. Limnology and Oceanography, 19, 846-848.

Movilla J, Calvo E, Pelejero C, Coma R, Ribes M, Serrano E, Fernández-Vallejo P (2012) Calcification reduction and recovery in native and non-native Mediterranean corals in response to ocean acidification. Journal of Experimental Marine Biology and Ecology, accepted.

Muehllehner N, Edmunds PJ (2008) Effects of ocean acidification and increased temperature on skeletal growth of two scleractininan corals, Pocillopora meandrina and Porites rus. Proceedings of the 11th International Coral Reef Symposium, Ft. Lauderdale, Florida.

Nonaka M, Muzik K (2009) Recent harvest records of commercially valuable precious corals in the Ryukyu ArchipelagoMar Ecol Prog Ser 397: 269-278.

Orr, J C., Fabry, VJ, Aumont, O, Bopp, L, Doney, SC, Feely, RA, Gnanadesikan, A, Gruber, N, Ishida, A, Joos, F, Key, RM, Lindsay, K, Maier-Reimer, E, Matear, R, Monfray, P, Mouchet, A, Najjar, RG, Plattner, GK, Rodgers, KB, Sabine, CL, Sarmiento, JL, Schlitzer, R, Slater, RD, Totterdell, IJ, Weirig, MF, Yamanaka, Y, and Yool, A (2005) Antropogenic ocean acidification over the twenty-first century and its impact on calcifying organisms, Nature, 437, 681-686.

Palmer AR (1983) Relative cost of producing skeletal organic matrix versus calcification: evidence from marine gastropods. Marine Biology 292, 287-292.

Palmer AR (1992) Calcification in marine molluscs: how costly is it? Proceedings of the National 
Academy of Sciences of the United States of America 89, 1379-82.

Perez FF, Fraga F (1987) A precise and rapid analytical procedure for alkalinity determination. Marine Chemistry 21, 169-182.

Perez FF, Rios AF, Rellán T, Alvarez M (2000) Improvements in a fast potentiometric seawater alkalinity determination. Ciencias Marinas 26, 463-478.

Plattner GK, Knutti R, Joos F et al. (2008) Long-term climate commitments projected with climatecarbon cycle models. Journal of Climate, 21, 2721-2751.

Plummer LN, Mackenzie FT (1974) Predicting mineral solubility from rate data: application to the dissolution of Mg- calcites. American Journal of Sciences, 274:61-83.

Previati M, Scinto A, Cerrano C, Osinga R, (2010) Oxygen consumption in Mediterranean octocorals under different temperatures. Journal of Experimental Marine Biology and Ecology 390, 39-48.

R Development Core Team (2007) R: a language and environment for statistical computing. R Foundation for Statistical Computing, Vienna, Austria. ISBN 3-900051- 07-0. http://www.Rproject.org

Ries JB, Cohen AL, \& McCorkle DC (2009) Marine calcifiers exhibit mixed responses to $\mathrm{CO}_{2}$-induced ocean acidification. Geology, 37(12), 1131-1134.

Ries JB, Cohen AL and McCorkle DC (2010) A nonlinear calcification response to $\mathrm{CO}_{2}$-induced ocean acidification by the coral Oculina arbuscula. Coral Reefs 29 (3): 661-674.

Ries JB (2011) A physicochemical framework for interpreting the biological calcification response to $\mathrm{CO}_{2}$-induced ocean acidification. Geochimica et Cosmochimica Acta 75, 4053-4064.

Robbins LL, Hansen ME, Kleypas JA, Meylan SC (2010) CO2calc-A user-friendly seawater carbon calculator for Windows, Max OS X, and iOS (iPhone): U.S. Geological Survey Open-File Report 2010-1280, $17 \mathrm{p}$.

Rodolfo-Metalpa R, Martin S, Ferrier-Pages C, Gattuso JP (2010a) Response of the temperate coral Cladocora caespitosa to long-term exposure to $p \mathrm{CO}_{2}$ and temperature levels projected for the year 2100 AD. Biogeosciences, 7, 289-300.

Rodolfo-Metalpa R, Lombardi C, Cocito S, Hall-Spencer J, and Gambi MC. (2010b) Effects of ocean acidification and high temperatures on the bryozoan Myriapora truncata at natural $\mathrm{CO}_{2}$ vents. Marine Ecology: an evolutionary perspective 31:447-456. 
. (2011) Coral and mollusk resistance to ocean acidification adversely affected by warming. Nature Climate Change, 1, 308-312.

Rossi S (2002) Environmental factors affecting the trophic ecology of benthic suspension feeders. $\mathrm{PhD}$ Thesis, University of Barcelona.

Rossi S, Gili JM, Coma R, Linares C, Gori A, Vert N (2006) Seasonal cycles of protein, carbohydrate and lipid concentrations in Paramuricea clavata: (anthozoa, octocorallia): evidences for summer autumn feeding constraints. Marine Biology, 149, 643-651.

Rossi S, Tsounis G (2007) Temporal and spatial variation in protein, carbohydrate, and lipids in Corallium rubrum (Anthozoa, Octocorallia) Marine Biology, 157, 429-439.

Rossi S, Tsounis G, Orejas C, Padrón T, Gili JM, Bramanti L, Teixidó N, Gutt J (2008) Survey of deep-dwelling red coral (Corallium rubrum) populations at Cap de Creus (NW Mediterranean). Marine Biology, 154, 533-545.

Rossi S, Bramanti L, Broglio E, Gili JM (2012). Trophic impact of long-lived species indicated by population dynamics in a short-lived hydrozoan, Eudendrium racemosum Mar Ecol Prog Ser. 467: 97-111, doi: 10.3354/meps09848

Ruiz J, Antequera T, Andres AI, Petron MJ, Muriel E (2004) Improvement of a solid phase extraction method for analysis of lipid fractions in muscle foods. Anal Chem Acta 520:201-205.

Russell J, Werne J (2007) The Use of solid phase extraction columns in fatty acid purification. Organic Chemistry, 38(1), 48-51.

Santangelo G, Maggi E, Bramanti L, Bongiorni L (2004) Demography of the over-exploited Mediterranean red coral (Corallium rubrum L. 1758). Scientia Marina, 68 (Suppl. 1), 199204.

Santangelo G, Bramanti L, Iannelli M (2007) Population dynamics and conservation biology of the over-exploited Mediterranean red coral. Journal of Theoretical Biology, 244, 416-423.

Santangelo G, Cupido R, Cocito S, Bramanti L, Tsounis G, Iannelli M (2012a) Demography of long-lived octocorals: survival and local extinction. Proceedings of the 12th International Coral Reef Symposium, Cairns, Australia, 9-13 July 2012 12A Life-history and reproduction.

Santangelo G, Bramanti L, Rossi S, Tsounis G, Vielmini I, Lott C, Gili JM (2012b) Patterns of variation in recruitment and post-recruitment processes of the Mediterranean precious gorgonian coral Corallium rubrum. J Exp Mar Biol Ecol 411: 7-13. 
Schneider A, Wallace DWR, Körtzinger A (2007) Alkalinity of the Mediterranean Sea. Geophysical Research Letters 34, 1-5.

Schneider A, Tanhua T, Körtzinger A, and Wallace DWR (2010) High anthropogenic carbon content in the eastern Mediterranean, J. Geophys. Res., 115, C12050, doi:10.1029/2010JC006171.

Slattery M, McClintock JB and Heine JN (1995) Chemical defenses in Antarctic soft corals: evidence for antifouling compounds. Journal of Experimental Marine Biology and Ecology $190,61-77$.

Smith AM, Key MM Jr, Gordon DP (2006) Skeletal mineralogy of bryozoans: Taxonomic and temporal patterns. Earth-Sci. Rev. 78: 287-306.

Suggett DJ, Hall-Spencer JM, Rodolfo-Metalpa R, Boatman TG, Payton R, Tye Pettay D, Johnson VR, Warner ME and Lawson T (2012) Sea anemones may thrive in a high $\mathrm{CO}_{2}$ world. Global Change Biology 18, 3015-3025, doi: 10.1111/j.1365-2486.2012.02767.x

Touratier and Goyet (2009) Decadal evolution of anthropogenic $\mathrm{CO}_{2}$ in the northwestern Mediterranean Sea from the mid-1990s to the mid-2000s, Deep Sea Research Part I, 56, $1708-1716$

Touratier F, and Goyet C (2011) Impact of the Eastern Mediterranean Transient on the distribution of anthropogenic $\mathrm{CO}_{2}$ and first estimate of acidification for the Mediterranean Sea. Deep Sea Research Part I: Oceanographic Research Papers 58, 1-15.

Torrents O, Tambutte E, Caminiti N, Garrabou J (2008) Upper thermal thresholds of shallow vs. deep populations of the precious Mediterranean red coral Corallium rubrum (L.): assessing the potential effects of warming in the NW Mediterranean. Journal of Experimental Marine Biology and Ecology, 357, 7-19.

Trotter J et al. (2011) Quantifying the $\mathrm{pH}$ 'vital effect' in the temperate zooxanthellate coral Cladocora caespitosa: Validation of the boron seawater $\mathrm{pH}$ proxy. Earth and Planetary Science Letters, 303, 163-173.

Tsounis G, Rossi S, Gili JM, Arntz W (2007) Red coral fishery at the Costa Brava (NW Mediterranean): case study for an over harvested precious coral. Ecosystems, 10, 975-986.

Tsounis G, Rossi S, Grigg R, Santangelo G, Bramanti L, Gili JM (2010) The exploitation and conservation of precious corals. In: Oceanography and Marine Biology: An Annual Review (eds Gibson R, Atkinson R, and Gordon J ), 48, 161-212. 
Tsounis G, Martinez L, Bramanti L, Viladrich N, Gili JM, Martinez A, Rossi S. (2012). Anthropogenic effects on reproductive effort and allocation of energy reserves in the Mediterranean octocoral Paramuricea clavata. MEPS 449:161-172

Tsounis G, Rossi S, Bramanti L, Santangelo G (2013) Management hurdles for sustainable harvesting of Corallium rubrum. Mar.Policy. htt p://dx.doi.org/10.1016/j.marpol.2012.12.010i

Turon X and Becerro MA (1992) Growth and survival of several ascidian species from the northwestern Mediterranean. Mar Ecol Prog Ser 82: 235-247.

Vielzeuf D, Garrabou J, Baronnet A, Grauby O, Marschal C (2008) Nano to macroscale biomineral architecture of red coral (Corallium rubrum). American Mineralogist 93: 1799-1815

Wicks L and Roberts JM (2012). Benthic invertebrates in a high- $\mathrm{CO}_{2}$ world. Oceanography and Marine Biology Annual Review, 50, 127-188.

Wong KKW, Lane AC, Leung PTY, Thiyagarajan V (2011) Response of larval barnacle proteome to CO2-driven seawater acidification. Comparative Biochemistry and Physiology Part D: Genomics and Proteomics 6: 311-321.

Wood HL, Spicer JI and Widdicombe S (2008) Ocean acidification may increase calcification rates, but at a cost. Proc. R. Soc. B 275, 1767-1773 doi:10.1098/rspb.2008.0343

Yilmaz A, De Lange G, Dupont S, Fine M, Fowler SW, Gattuso JP, Gazeau F, Gehlen M, Goyet C, Jeffree R, Montagna P, Rees AP, Reynaud S, Rodolfo-Metalpa R, Ziveri P, Briand F (2008) Impact of Acidification on Biological, Chemical and Physical Systems in the Mediterranean \& Black Sea Mediterranean, Mediterranean Science Committee (CIESM), Monograph Series, Vol. 36, 2009, pp. 124.

Ziveri P (2012) Research turns to acidification and warming in the Mediterranean Sea, IMBER (Integrated Marine Biogeochemistry and Ecosystem Research), Newsletter, Issue n.\#20, May 2012.

\section{Figure captions}

Fig S1. Colony of Corallium rubrum in the experimental aquarium 
Fig. S2. Experimental setup used to control and modify seawater $\mathrm{pH}$ in each aquarium. A) and B) large 1501 tanks for seawater conditioning at $\mathrm{pH}_{\mathrm{T}} 7.81$ and 8.10, respectively; C) glass electrodes for $\mathrm{pH}$ and PT100 probes for temperature measurements; D) pH controller and data logger; E) solenoid valves; F) soda lime filter; G) $50 \mathrm{~kg} \mathrm{CO}_{2}$ bottle; H) and I) control and low $\mathrm{pH}$ experimental aquaria, respectively (three replicates per treatment); J) Microbubble diffusers.

Fig. S3. Examples of Scanning Electron Microscope (SEM) images of the three types of sclerites observed in C. rubrum.

Fig. S4. Fatty acids composition. SAFA: total Saturated Fatty Acids; MUFA: Mono Unsaturated Fatty Acids; PUFA: Poly Unsaturated fatty acids.

Fig. 1. Calcification rates of $C$. rubrum after 314 days under low $\mathrm{pH}_{\mathrm{T}}$ (grey bars, $\mathrm{pH}_{\mathrm{T}} 7.81$ units) and control conditions (black bars, $\mathrm{pH}_{\mathrm{T}} 8.10$ units). Calcification rates are expressed as $\mathrm{mg} \mathrm{CaCO}_{3}$ per gram of initial weight per day. $\mathrm{n}=15$, error bars represent SE.

Fig. 2. Total organic matter $\%$ in the coenenchyma of Corallium rubrum colonies $(n=24)$ during the whole experiment. Black and grey bars represent control $\left(8.10 \mathrm{pH}_{\mathrm{T}}\right.$ units $)$ and treatment $\left(7.81 \mathrm{pH}_{\mathrm{T}}\right.$ units), respectively (mean $\pm \mathrm{SD}$ ).

Fig. 3. Total protein (a), lipid (b) and carbohydrate (c) concentration ( $\mu \mathrm{g} \mathrm{mg}^{-1} \mathrm{OM}$ ) in the coenenchyma of Corallium rubrum colonies $(n=24)$ during all the periods of time when colonies were sampled. Black and grey bars represent control $\left(\mathrm{pH}_{\mathrm{T}} 8.10\right.$ units) and treatment $\left(7.81 \mathrm{pH}_{\mathrm{T}}\right.$ units), respectively (mean $\pm \mathrm{SD}$ ). $\mathrm{CV}=$ coefficient of variation.

Fig. 4. Total fatty acid concentration $\left(\mu \mathrm{g} \mathrm{mg}^{-1} \mathrm{OM}\right)$ in the coenenchyma of Corallium rubrum colonies $(\mathrm{n}=24)$. Black and grey bars represent control $\left(\mathrm{pH}_{\mathrm{T}} 8.10\right.$ units $)$ and treatment $\left(7.81 \mathrm{pH}_{\mathrm{T}}\right.$ units), respectively (mean $\pm \mathrm{SD}$ ). $\mathrm{CV}=$ coefficient of variation. 

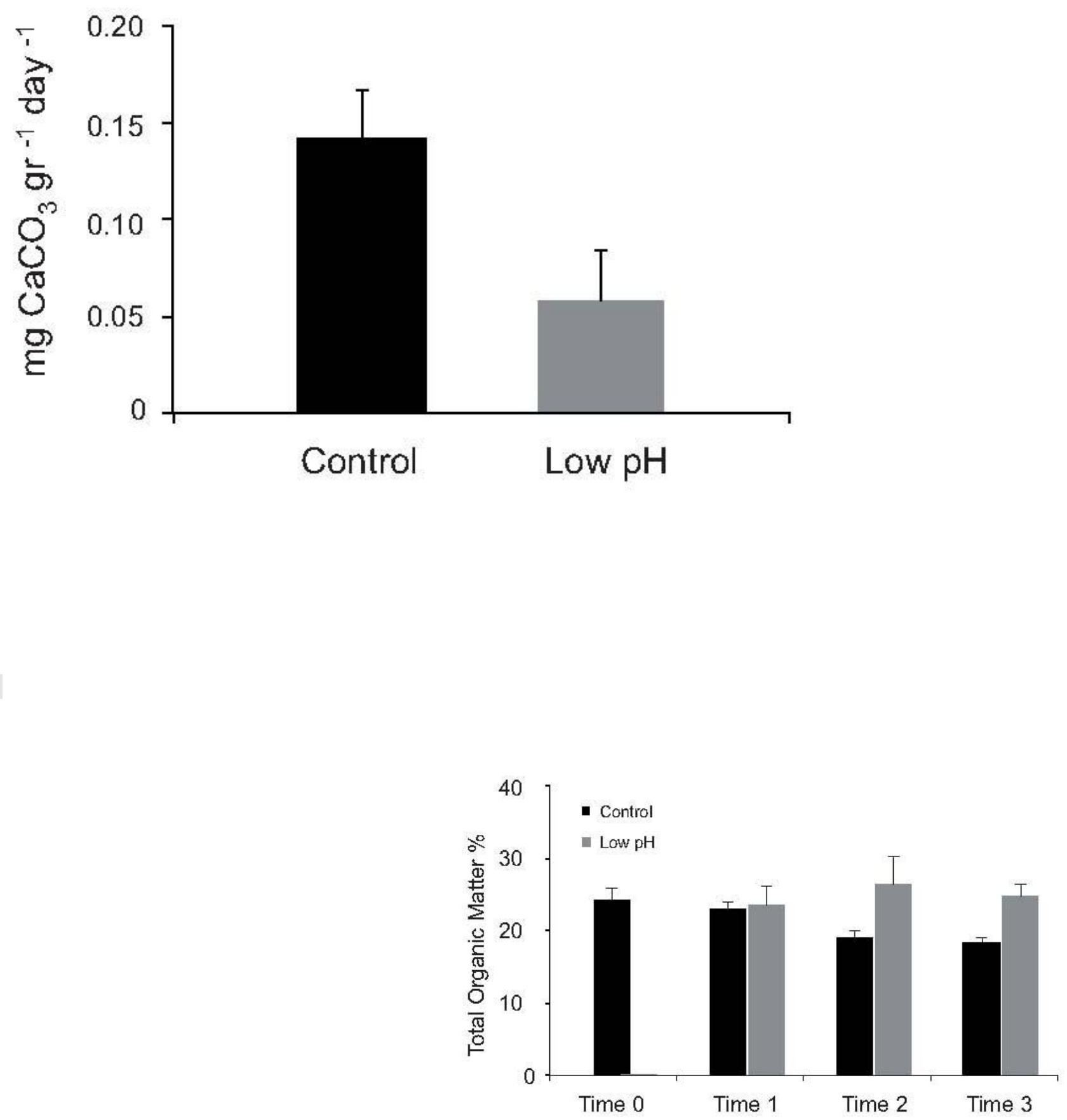
(a)

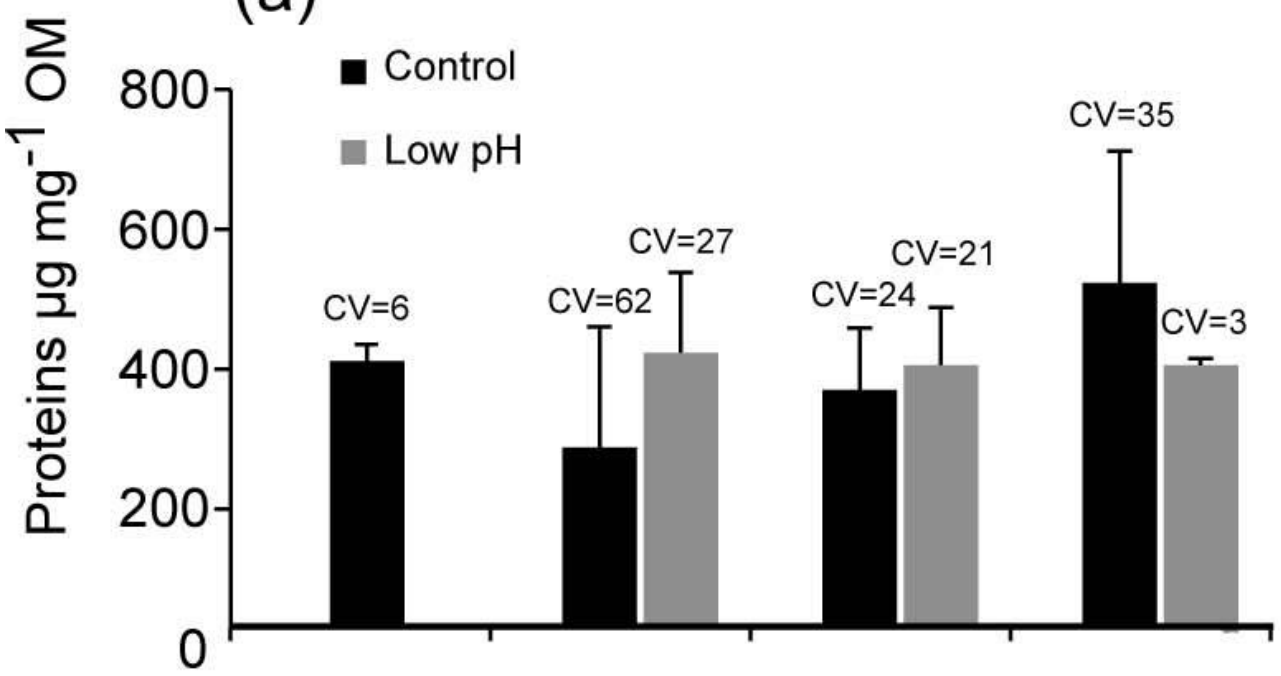

(b)
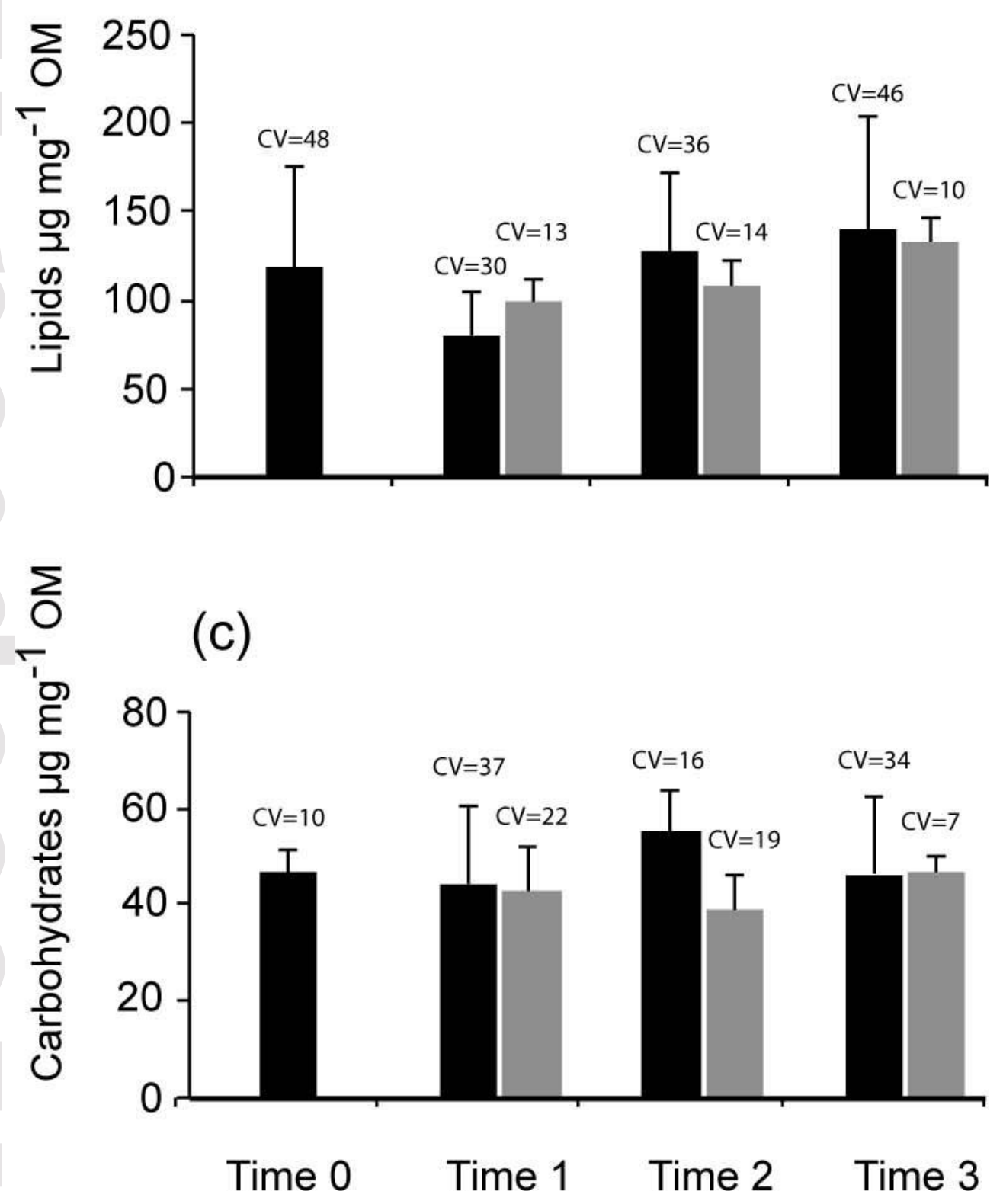


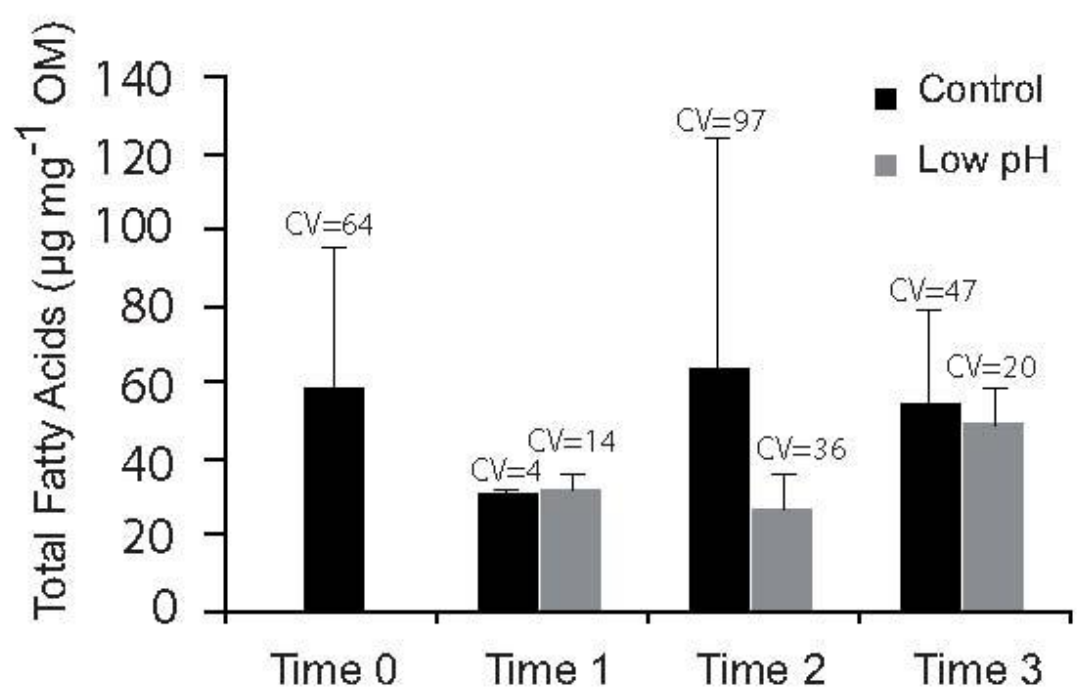

